\title{
Asbestos and insurance interests continue to use discredited scientific argument to sell asbestos and to deny justice to asbestos victims
}

Kathleen Ruffi*, Eliezer João de Souzaii, Fernanda Giannasiii, Evelyn Glenskiv, Marc Hindryv, Linda Reinsteini, Adrian Prietovii, Gopal Krishnaviii, Laurie Kazan-Allen ${ }^{\text {ix }}$, Eric Jonckheere ${ }^{\mathrm{x}}$, Robert Vojakovic ${ }^{\mathrm{xi}}$, and Pierrette Iselin ${ }^{\text {xii }}$

Chrysotile asbestos represents ninety-five percent of all asbestos sold over the past century. For more than two decades the global asbestos trade has consisted entirely of chrysotile asbestos. ${ }^{1}$ For this reason, it has been imperative for the asbestos industry, in order to ensure its survival, to claim that chrysotile asbestos can be used safely and that only other amphibole forms of asbestos are harmful.

The scientific evidence is overwhelming that chrysotile asbestos causes deadly diseases, such as asbestosis, mesothelioma, lung, and other cancers, and that use of chrysotile asbestos should stop. . $^{2,3,4,5,6}$ The asbestos industry has, therefore, spent millions of dollars paying scientists to carry out a misinformation campaign to deny the scientific evidence and claim that, while amphibole asbestos causes harm to health, chrysotile asbestos does not. ${ }^{7}$

\section{The lung fibre count fallacy}

In 2005, the asbestos lobby organization (the Asbestos Institute in Quebec) paid toxicologist David Bernstein a million dollars to develop and publish an article that argued that chrysotile asbestos can be safely used. ${ }^{8}$ The expedient theory that Bernstein created was that "low exposures to pure chrysotile do not present a detectable risk to health" 9 because chrysotile asbestos fibres are quickly expelled from the lungs. The Asbestos Institute was thrilled and put out a media release stating that it was buoyed by the results of Bernstein's biopersistence in the lungs study and would focus on disseminating the results of the study to international bodies. ${ }^{10}$ Bernstein's "biopersistence" theory was based on flawed experiments with rats and mice. ${ }^{11}$ In 2013, Bernstein invoiced two asbestos lobby organizations $\$ 200,000^{12}$ to write a second article ${ }^{13}$ repeating the same argument.

As well as being used to promote the sale of asbestos, this misleading argument focused on asbestos fibres in the lungs, also being exploited to unjustly deny compensation to workers harmed by chrysotile asbestos in Germany and elsewhere. ${ }^{14,15,16}$ There are several key concerns regarding Bernstein's discredited scientific argument. For one, chrysotile asbestos fibres accumulate in the pleura surrounding the lung, which is the location where pleural mesothelioma occurs. As the Collegium Ramazzini notes, "Multiple studies have demonstrated that chrysotile fibers are the predominant type of asbestos fiber found in pleural mesothelioma tissue. The relative abundance of chrysotile fibers in mesothelioma tissue contrasts with their relative scarcity in lung tissue."17 The absence of chrysotile asbestos fibres in the lungs does not constitute evidence of lack of harm. ${ }^{18}$ The evidence is overwhelming that people who have been exposed to chrysotile asbestos develop deadly asbestos-related diseases. ${ }^{19}$ Tobacco smoke is quickly expelled from the lungs but causes lung cancer..$^{20}$ As noted by the International Network for Epidemiology in Policy, every reputable scientific body in the world that has examined the health risks of chrysotile asbestos has rejected Bernstein's theory that chrysotile asbestos fibres

\footnotetext{
i Director, RightOnCanada, Canada (*Corresponding Author: kruff@starlynx.ca)

ii President, Associação Brasileira dos Expostos ao Amianto (ABREA), Brazil

iii Coordinator, Rede Virtual-Cidadã pelo Banimento do Amianto na América Latina, Brazil

iv Formerly with the Federal Association of Asbestos Victims Groups (Bundesverband der Asbestose Selbsthilfegruppen e.V.), Germany

${ }^{\vee}$ Association Nationale de Défense des Victimes de l'Amiante (ANDEVA), France

vi President, Asbestos Disease Awareness Organization (ADAO), USA

vii Founder and Spokesperson, Unidos Contra el Asbesto (UCA), Chile

viii Ban Asbestos Network of India (BANI) - ToxicsWatch Alliance (TWA), India

${ }^{i x}$ Co-ordinator, International Ban Asbestos Secretariat, UK

x President, Association belge des Victimes de l'amiante (ABEVA), Belgium

xi President, Asbestos Diseases Society of Australia

xii Comité d'orientation et de défense des victimes de l'amiante (CAOVA), Switzerland
}

Received: September 2018

Accepted for Publication: December 2018

Published Online: April 2019

(C) 2019 by the author(s). This article is distributed under the terms and conditions of the Creative Commons Attribution ( $\underline{\text { CC BY }}$ ) license. 
are harmless. ${ }^{21}$ Only the asbestos industry and scientists with financial ties to asbestos interests support Bernstein's theory. ${ }^{22,23}$

Over the past decade, asbestos interests have paid Bernstein millions of dollars to write articles and to lobby governments around the world and United Nations (UN) institutions to deny harm caused by chrysotile asbestos and promote the use of chrysotile asbestos in homes, schools, buildings, and infrastructure. ${ }^{24}$ He has been a regular participant at the strategy meetings of the international asbestos lobby organization (International Chrysotile Association) and has been paid by the asbestos industry to make presentations promoting chrysotile asbestos in India, Zimbabwe, Malaysia, Brazil, Philippines, Quebec, Ukraine, Mexico and elsewhere. ${ }^{25,26,27}$ The millions of dollars that asbestos interests have paid Bernstein have served their interests well. Bernstein's discredited biopersistence in the lungs theory is the leading propaganda weapon used by the asbestos industry to continue its deadly trade.

It is noteworthy that in strategizing to block the listing of chrysotile asbestos as a hazardous substance at the UN Rotterdam Convention Conference of the Parties, which will take place in Geneva from April 29 to May 9, 2019, as the Convention's scientific committee has repeatedly recommended, asbestos interests plan to use Bernstein's 2003 article, "Biopesistence of Canadian Chrysotile Asbestos by Inhalation", to argue that chrysotile asbestos is not hazardous. ${ }^{28,29}$

\section{Using lung fibre counts to dismiss compensation claims of asbestos victims}

In countries where asbestos has been banned, the issue of asbestos fibres in the lungs is being used in a different but equally deceptive manner by vested interests, such as insurance entities, in order to reject compensations claims from workers. In Germany, about 10,000 workers have had their compensation claims unjustly dismissed on the basis of this false argument that, for a claim to be upheld, there must be evidence of chrysotile asbestos fibres in the worker's lungs., ${ }^{30,31}$

In an article published in the European Respiratory Journal, the authors claim to be putting forward new, significant evidence in support of requiring chrysotile asbestos fibres to be found in workers' lungs when considering workers' compensation claims. ${ }^{32}$ The authors state that their article provides "new insights" and that "This issue is of high significance for differential diagnosis, risk assessment, and occupational compensation."

Far from being insightful, the article lacks credibility. As Oliver et al. point out, ${ }^{33}$ the study design is faulty: "Significant scientific problems in patient/sample selection and applied methods exist. First, the small sample size: only
$12(0.05 \%)$ of the 23,955 cases were analyzed with two investigations; only six had electron microscopic examination of tissue." The article's assertions are, however, financially beneficial to insurance entities with whom the authors have direct, undeclared, financial ties. ${ }^{34}$

In a media release promoting their article, the authors state: "Last but not least, the question of the detectability of asbestos fibers in the lungs is crucial for assessing the risk of asbestos in the workplace. From this follows the decision as to whether a lung disease can be recognized as an occupational disease so that those affected are entitled to compensation." (Translation) 35

The authors falsely claim that the scientific community has not yet concluded whether or not chrysotile asbestos is hazardous. Shamefully, they cite Bernstein's discredited, asbestos-industry-funded articles as "evidence" of this alleged uncertainty in the scientific community regarding chrysotile asbestos. In this way, the authors irresponsibly manufacture doubt.

Reputable scientific organizations, such as the Collegium Ramazzini, have specifically pointed out how relying on lung fiber counts in determining worker compensation cases is unjust and unacceptable:

Asbestos fiber counts obtained from human lung tissue are now recognized to be a highly insensitive measure of past exposure to chrysotile asbestos. Chrysotile asbestos fibers are now well documented to have only a short residence time in lung tissue, and therefore their measurement in the lung cannot be used as a measure of cumulative past exposure. For these reasons, relying on lung tissue analysis for the diagnosis and compensation of asbestos-related disease - while ignoring the history of occupational exposure - is unacceptable. ${ }^{36}$

As the Collegium Ramazzini document concludes: “... the Collegium Ramazzini emphasizes that a carefully obtained history of occupational exposure to asbestos is the cornerstone of an accurate diagnosis of the diseases caused by asbestos."

Workers were subjected to gross injustice when corporations and governments allowed them to be exposed to asbestos harm long after it was known that all asbestos is deadly. It is unconscionable that now the workers and their families are being subjected to further gross injustice by the denial of compensation to which they are entitled on the basis of inaccurate, distorted scientific arguments.

A number of organizations representing and advocating for asbestos victims in Germany, France, Switzerland, Belgium, the UK, Canada, India, Australia, USA, Chile and Brazil called on the European Respiratory Journal (ERJ) to retract the Feder et al. article because it is deceptive and will cause harm to asbestos victims. ${ }^{37}$

The ERJ refused to do so and declined to publish their letter to the editor. ${ }^{38}$ 
The ERJ has a policy of refusing submissions and work from authors with ties to the tobacco industry. This is a policy to be lauded. Like the tobacco industry, the asbestos industry has a long, sordid history of distorting and suppressing scientific evidence and corrupting government policy, resulting in huge numbers of painful, preventable deaths. Bernstein worked for eighteen years for the tobacco industry before switching to serving the asbestos industry. Journals, like Critical Reviews in Toxicology, which published Bernstein's million-dollar-asbestos-industry-funded article, and many other articles denying harm caused by chrysotile asbestos, was run by editors and scientists with deep financial ties to the tobacco industry and published articles denying tobacco harm. ${ }^{39}$

The ties and similarities between the asbestos industry and the tobacco industry are clear ${ }^{40,41}$

\section{References}

1. United States Geological Survey, World Asbestos Production By Type, 1900 to 2012. Available from: rightoncanada.ca/wp-content/uploads/2016/01/Worldasbestos-production-by-type-1900-to-20121.jpg

2. Collegium Ramazzini, 2004. Call for an International Ban on Asbestos. Collegium Ramazzini, 2010. Asbestos Is Still With Us: Repeat Call for a Universal Ban. International Agency for Research on Cancer. Asbestos (chrysotile, amosite, crocidolite, tremolite, actinolite, and anthophyllite). 2012; Vol. 100c. Available from: http://monographs.iarc.fr/ENG/Monographs/vol100C/mono 100C-11.pdf.

3. International Commission on Occupational Health. ICOH Statement on Global Asbestos Ban and the Elimination of Asbestos-related Diseases. 2013. Available from: http://www.icohweb.org/site/news-detail.asp?id=83

4. World Federation of Public Health Associations. Global ban on the mining and use of asbestos. 2005. Available from: http://www.wfpha.org/tl files/doc/resolutions/positionpape rs/enrivonment/GlobalBanMining\&A sbestos.pdf

5. World Health Organization. Elimination of asbestos-related diseases. 2006. Available from: http://whqlibdoc.who.int/hq/2006/WHO SDE OEH 06.03 eng.pdf

6. World Health Organization. Asbestos: elimination of asbestos-related diseases. Fact Sheet. Updated June 2016. Available from: http://www.who.int/mediacentre/factsheets/fs343/en/inde x.html. World Health Organization. Chrysotile Asbestos. 2014. Available from: http://www.who.int/ipcs/assessment/public health/chrysoti le asbestos summary.pdf.
It is time that the European Respiratory Journal and reputable scientific journals adopt a policy to refuse submissions from authors with ties to asbestos interests who put forward discredited and deceptive arguments to deny or manufacture doubt about harm caused by asbestos.

Acknowledgments: No funding was received for this article.

Disclosures: The lead author, Kathleen Ruff, has no conflicting interests. She works pro bono to stop the continuing sale of asbestos and to call for just compensation for asbestos victims. The co-authors represent organizations working towards a global ban on asbestos and to achieve just compensation for asbestos victims. Some of these organization at times receive donations from asbestos victims and their families, public charities, trade unions and lawyers involved in representing asbestos victims.

7. McCulloch J, Tweedale G. Defending the Indefensible: The Global Asbestos Industry and its Fight for Survival. Oxford University Press.

8. Mealey's International Asbestos Liability Report, November 19, 2003.

9. Bernstein D, Hoskins J. The health effects of chrysotile: Current perspective based upon recent data. Regul Toxicol Pharmacol. Aug 2006 ; 45(3):252-64.

10. The Asbestos Institute, Press Release, "With new supporting evidence, Quebec chrysotile is entitled to fair and balanced treatment." September 9, 2004.

11. Pézerat H. Chrysotile Biopersistence. The Misuse of Biased Studies. Int J Occup Environ Health 2009; 15:102-106.

12. Pigg BJ, Treasurer, International Chrysotile Association. Deposition, June 18, 2013, page 82.

13. Bernstein D, Dunnigan J, Hesterberg $T$, et al. Health risk of chrysotile revisited. Crit Rev Toxicol 2013; 43: 154-183.

14. Baur X. Asbestos: Socio-legal and Scientific Controversies and Unsound Science in the Context of the Worldwide Asbestos Tragedy - Lessons to be Learned. Pneumologie 2016: 70(6): 405-412.

15. Woitowitz H-J. The theory of asbestos bodies is dead German Mesothelioma register - what next? Zbl Arbeitsmed 2016: 66(4): 232-238.

16. Baur X. Response to the letter of R. Merget, I. Feder and A. Tannapfel. Pneumologie, 2017; pp. 121-123.

17. Landrigan PJ on behalf of the Collegium Ramazzini. Comments on the 2014 Helsinki Consensus Report on Asbestos. Ann Glob Health. 2016 Jan-Feb;82(1):217-20. DOI: 10.1016/j.aogh.2016.01.018.

18. Landrigan P.J, Lemen RA on behalf of the Collegium Ramazzini. Letter to the Editor (April 4, 2018) concerning the paper "Histological findings and lung dust analysis as the 
basis for occupational disease compensation in asbestosrelated lung cancer in Germany." November 2018. International Journal of Occupational Medicine and Environmental Health. Available from: https://doi.org/10.13075/ijomeh.1896.01345.

19. International Agency for Research on Cancer, 2012. Monograph. Asbestos (Chrysotile, Amosite, Crocidolite, Tremolite, Actinolite, and Anthophyllite). Vol. 100c. Available from:

http://monographs.iarc.fr/ENG/Monographs/vol100C/mono 100C-11.pdf

20. Centers for Disease Control and Prevention (US); National Center for Chronic Disease Prevention and Health Promotion (US); Office on Smoking and Health (US). How Tobacco Smoke Causes Disease: The Biology and Behavioral Basis for Smoking-Attributable Disease: A Report of the Surgeon General. Atlanta (GA): Centers for Disease Control and Prevention (US); 2010. 5, Cancer. Available from: https://www.ncbi.nlm.nih.gov/books/NBK53010/

21. The International Network for Epidemiology in Policy (previously called The Joint Policy Committee of the Societies of Epidemiology). Position Statement on Asbestos. June 4, 2012. Available from: https://epidemiologyinpolicy.org/documents/03.JPC-SEPosition_Statement_on_Asbestos-June 4 2012Full Statement and Appendix A.pdf.

22. McCulloch J, Tweedale G. (2008). Defending The Indefensible: The Global Asbestos Industry and its Fight for Survival. Oxford University Press. ISBN 978-0-19-953485-2.

23. Michaels, D. (2008). Doubt is Their Product: How Industry's Assault on Science Threatens Your Health. Oxford University Press, New York.

24. Pigg BJ, Treasurer, International Chrysotile Association. Deposition, June 18, 2013.

25. Abad RL. Expert pushes for controlled use ban on asbestos (sic). Business Mirror, November 19, 2013, Available from: https://rightoncanada.ca/wpcontent/uploads/2019/03/Bernstein-Philippines-promotesasbestos-use-Nov-192013.pdf.

26. Zirebwa V. Let's Revive Shabani, Mashava Mines. Zimbabwe Herald, June 9, 2014. Available from: http://allafrica.com/stories/201406090700.html.

27. International Chrysotile Association, Minutes, Executive Committee meeting, November 29, 2011.

28. Rotterdam Convention COP-9 MEETING - 2019, page 15, International Chrysotile Association, January 2019. Available from: http://chrysotileassociation.com/data/ICA RotterdamConvention 2019-COP9 v5.pdf.

29. Eurasian Economic Committee, United Front in Defense of Chrysotile Asbestos. Available from: https://rusplt.ru/society/stroitelnyiy-gornyiy-len-35653.html. (translated)

30. Woitowitz H-J, Baur X (2018). Misleading "New Insights into the Chrysotile Debate". Pneumologie. https://doi.org/10.1055/s-0044-102169.
31. Baur X, Belpoggi F, Budnik LT et al. Letter To The Editor (February 14, 2018) Concerning The Paper "Histological Findings and Lung Dust Analysis as the Basis for Occupational Disease Compensation in Asbestos-Related Lung Cancer in Germany". International Journal of Occupational Medicine and Environmental Health 2018; 31(6):1-3. Available from: https://doi.org/10.13075/ijomeh.1896.01332

32. Feder IS, Tischoff I, Theile A, Schmitz I, Merget R, Tannapfel A. The asbestos fibre burden in human lungs: new insights into the chrysotile debate. Eur Respir J 2017: 49(6). Available from:

http://eri.ersjournals.com/content/erj/49/6/1602534.full.pd f

33. Oliver LC, Belpoggi F, Budnik LT, et al. Correspondence regarding the article "The asbestos fibre burden in human lungs: new insights into the chrysotile debate". Eur Respir J 2017; 50: 1701644. https://doi.org/10.1183/13993003.01644-2017.

34. Woitowitz H-J, Baur X (2018). Misleading "New Insights into the Chrysotile Debate". Pneumologie, page 510, What about undeclared authors' Conflicts of Interest (COI)? https://doi.org/10.1055/s-0044-102169.

35. Lungenerkrankungen. Asbest ist unvergänglich. Presseinformation. Tannapfel, A. July 31, 2017. Available from:

http://news.rub.de/presseinformationen/wissenschaft/2017 -07-31-lungenerkrankungen-asbest-ist-unvergaenglich.

36. Collegium Ramazzini. Comments On The 2014 Helsinki Consensus Report On Asbestos. October 2015. Available from:

http://www.collegiumramazzini.org/download/Helsinki_Con sensus Asbestos Comments\%282015\%29.pdf

37. Ruff $\mathrm{K}$ et al. Letter to the Editor, European Respiratory Journal. August 15, 2017.

38. European Respiratory Journal - Reject decision on Manuscript ID ERJ-01770-2017, email from MuellerQuernheim J, November 7, 2017.

39. Velicer C, St. Helen G, Glantz SA. Tobacco papers and tobacco industry ties in regulatory toxicology and pharmacology. J Public Health Pol. October 2017. DOI 10.1057/s41271-017-0096-6.

40. Moodie et al. Profits and pandemics: prevention of harmful effects of tobacco, alcohol, and ultra-processed food and drink industries. The Lancet 2013; 381(9867): 670-679. Available from: https://www.sciencedirect.com/science/article/pii/S014067 3612620893

41. Michaels and Monforton. Manufacturing uncertainty: contested science and the protection of the public's health and environment. Am J Public Health 2005; 95 Suppl 1: S3948. Available from: https://ajph.aphapublications.org/doi/10.2105/AJPH.2004.0 $\underline{43059}$ 
Appendix A: Examples of payments made to David Bernstein by the International Chrysotile Association and other asbestos interests

- $\quad$ Payment by Union Carbide Corporation to David Bernstein, 2003 and 2005

In The Circuit Court Of The 11th Judicial Circuit In And For Miami-Dade County, Florida. Asbestos Litigation. Case No. 07-03229 Ca 42. Defendant Union Carbide Corporation's Supplemental Objections and Responses to Plaintiff's Second Set of Interrogatories, dated August 9, 2007:

"David M. Bernstein: In 2003 and 2005 respectively, Dr. Bernstein and others published two studies concerning the biopersistence of Calidria chrysotile asbestos. Those studies, as disclosed in the papers, were sponsored by Union Carbide. The total amount paid to support the studies was approximately $\$ 400,623.20$, which included all costs associated with the studies."

\section{- Email from David Bernstein to Clément Godbout, President, International Chrysotile Association, April 16,} 2010

De: David Bernstein [mailto:davidb@itox.chl

Envoye: 16 avril 2010 02:45

A : ICA; 'Jacques Dunnigan'

Objet: Re: Revisit the health risk assessment of chrysotile

Dear Clement,

Thank you very much for the confirmation. I look forward tow (sic) working with you and Jacques on this study.

I just returned from Jakarta where the presentations were well received. Sri said that the government was very positive about continuing the use of chrysotile in Indonesia. In addition to the presentations on the substitutes and the scientific persectives (sic), Sri asked me to present the presentation on the WHO's asbestos stance. This was given for both the government audience and the physicians/university audiance (sic) and well received by both. The Indonesian WHO representative was present and was very impressed.

Best regards,

David

David M. Bernstein, Ph.D.

Consultant in Toxicology

40 chemin de la Petite-Boissiere

1208 Geneva, Switzerland

\section{- Email from David Bernstein to Clément Godbout, President, ICA, 30 September 2010}

Invoice to : The international Chrysotile Association (1CA)

RE : « On the Need to Revisit the Health :Risk of Chrysotile »

Geneva, 30 September 2010

INVOICE : no. 009021

\section{For Services rendered for the period of September 2010}

- Revision and preparation of 5th \& 6th draft reports in coordination with Jacques Dunnigan on the need to revisit the health risk assessment of chrysotile asbestos.

- Revision of letter of invitation to co-authors and follow-up.

- Preparation \& presentation at 1CA Executive Board meeting, 8 September, Zurich

3.5 days Honorarium $(2,800 \mathrm{SF} /$ day $)$.................................... 9,800.00 Swiss Francs

Expenses: (reprints. tel, etc.) ........................................... 200.00 Swiss Francs

Travel Expenses: (see attached itemization) ..................... 214.00 Swiss Francs 
Total: 10,214.00 Swiss Francs

Please submit payment within 20 days by direct bank transfer to:

David M. Bernstein, Ph.D.

INVOICE: NO. 005024 for Services rendered for the period of April - May 2011

Chrysotile Health Risk Revisited: review of reviewer's comments from Journal Particle \& Fiber Toxicology. Researching and retrieval of cited references from reviewer statement.

Conference call \& preparation of presentations for meeting in Kuala Lumpur

Meeting in Kuala Lumpur, Malaysia, 25-29 June 2011

8 days

Honorarium (2,800 SF/day)

Expenses: (reprints, tel, etc.)

$22,400.00 \mathrm{SF}$

$400.00 \mathrm{SF}$

Travel Expenses (see attached itemization)

$7,367.45 \mathrm{SF}$

TOTAL

$30,167.45 \mathrm{SF}$

- Email from David Bernstein to Jean-Marc LeBlond, President, ICA, November 30, 2011

Dear Jean-Marc,

It was a pleasure seeing you again and working with you and the ICA in Dubai.

As agreed, I am sending you my invoice for the honorarium and expenses for the work requested during November 2011.

With best regards,

Sincerely yours,

David

David M. Bernstein, Ph.D.

INVOICE: no. 011028 for Services rendered for the period of October-November 2011

Chrysotile Health Risk Revisited: Review and assessment of revisions for the revised manuscript. Preparation of printed summary and of slide presentation for ICA meeting.

Participation in ICA meeting Dubai 28 Nov - 1 Dec, 2011.

- Email from David Bernstein to Chrysotile Institute, November 23, 2012

David M. Bernstein, Ph.D. CONSULTANT IN TOXICOLOGY

40 ch. de la Petite-Boissiere

Geneva Switzerland, $\mathrm{CH}-1208$

To: Chrysotile Institute, 1200 rue McGill College, Bureau 1640, Montreal (Quebec), Canada H3B 4G7

23 November 2012

INVOICE: no. 011022 for Services rendered for the period of November 2012 
Chrysotile Heath Risk Revisited: Revisions of the manuscript.

Honorarium manuscript $(2,800 \mathrm{SF} /$ day $)$............. 10,000.00 Swiss Francs

Total: 10,000.00 Swiss Francs

Please submit payment within 20 days by direct bank transfer to:

David M. Bernstein, Ph.D.

- $\quad$ Email from Pigg, ICA Treasurer, November 27, 2012

Subj: Re: Travel Expenses \& Fees for Kiev Scientific Conference, Nov. 21-22, 2012

Date: $11 / 27 / 2012$

From: AIABJPIGG@AOI.COM

To: david

CC: godbout, leblond

Dear David,

This will confirm that the following wire transfer was made earlier today, Nov. 27, 2012, to your new bank coordinates in Geneva:

13,636.04 - Travel expenses \& Fees for Kiev Conference

$10,000.00$ - Services rendered for October 2012

10,000.00 - Services rendered for November 2012

Total: 33,636.04 Swiss Francs

\section{- Email from Jean Marc Leblond, ICA President, January 24, 2013}

Subj: Reprints - Health Risk of Chrysotile Revisited

Date: 1/24/201311:59:41 A.M. Eastern Standard Time

From: jmarcleblond@2011ica.com

To: davidb@itox.ch

CC: clgod@bell.net, aiabjpigg@aol.com

Dear David:

Thanks for your recent messages. Glad to see that you managed to send copy to the Rotterdam Convention Secretariat.

Of course, please proceed reprints with a cover as you proposed and send charges to Mr. Bob Pigg.

Please arrange to send these reprints to my attention at:

ICA

1699 Boul. Frontenac East

Thetford Mines (Quebec)

CANADA G6G 6P6

We will arrange to distribute to various rCA (sic) members and associates.

Keep well.

Best regards,

Jean-Marc Leblond

- Email from David Bernstein to ICA re "our" publication, January 24, 2013 
From: David Bernstein

Sent: Thursday, January 24, 2013 7:08 AM

Thursday, January 24, 2013 AOL: AlABJPigg

ICA-Pigg 136

To: C GODBOUT

Cc: Jean-Marc Leblond; Bob Pigg

Subject: Re: Chrysotile references

Dear Clement,

Thanks for your confirmation.

Also can you let me know to whom the reprints should be addressed?

Finally, if you have not seen this, our publication is already distributed in the European Commission.

httpllyoutu.be/nYJFC-jrC-A

Best regards,

David 